\section{Comparing Cultivars of Three Cool-season Turfgrasses for Nitrogen Recovery in Clippings}

\author{
Haibo Liu ${ }^{1}$ \\ Department of Horticulture, 253 Poole Agriculture Center, Clemson University, \\ Clemson, SC 29634-0319
}

\author{
Richard J. Hull \\ Department of Plant Sciences, University of Rhode Island, Kingston, RI 02881
}

Additional index words. Festuca arundinacea, Lolium perenne, nitrogen budget, nitrogen use efficiency, Poa pratensis, turf-soil ecosystem

\begin{abstract}
Economic and environmental concerns over nitrogen (N) fertilization of turfgrasses are prompting serious considerations of how to best use various $\mathrm{N}$ pools in turf-soil ecosystems. Nitrogen in clippings is receiving special consideration but information on how large and variable this $\mathrm{N}$ source might be for different turfgrasses is limited. Therefore, a field study investigated growth of and $\mathrm{N}$ recovery in clippings from 10 cultivars each of kentucky bluegrass (Poa pratensis L.), perennial ryegrass (Lolium perenne L.), and tall fescue (Festuca arundinacea Schreb.) turf at the University of Rhode Island Turfgrass Research Station, Kingston, during 1990 and 1991 growing seasons. All turf had been established in 1985, 1986 or 1987 on an Enfield silt loam (Coarse loamy over sandy skeletal, mixed, mesic, Typic Dystrochrepts) and maintained under $N$ fertilization rate of $147 \mathrm{~kg}$ $\mathrm{N}$ ha/year. Daily clipping growth rate (DCG), leaf blade $\mathrm{N}$ concentration (NC), and daily $\mathrm{N}$ recovery rate (DNR) in clippings were compared across species and cultivars. Seasonal clipping yields ranged from $5152 \mathrm{~kg}$ dry weight/ha for tall fescue to $3680 \mathrm{~kg} \cdot \mathrm{ha}^{-1}$ for perennial ryegrass. Significant species differences in the amount and seasonal pattern of $\mathbf{N}$ recovery were identified. Cultivar differences in $\mathbf{N}$ recovery were greatest for kentucky bluegrass but much less for perennial ryegrass and tall fescue. Total $\mathrm{N}$ recovery in clippings ranged from 260 to $111 \mathrm{~kg} \mathrm{~N} / \mathrm{ha} /$ year generally exceeded $\mathrm{N}$ supplied as fertilizer, thus emphasizing potential importance of clipping $N$ in turf management.
\end{abstract}

Since the late 1960s, trends in turfgrass fertilization practices have been toward lowering nitrogen $(\mathrm{N})$ application rates. Aside from economic considerations, this trend has been driven by concerns over nitrate contamination of surface and ground waters. Numerous studies have demonstrated established turf to be an efficient scavenger of soil nitrate, to permit marginal nitrate leaching and to impede surface flow during heavy rain events (Petrovic, 1990; Hull and Liu, 2005). However, some measurements of nitrate leaching and runoff during establishment and post-establishment periods have indicated potential for significant $\mathrm{N}$ transport and water contamination (Geron et al., 1993; Easton and Petrovic, 2004; Petrovic and Easton, 2005). Leaching losses as high as $186 \mathrm{~kg} \mathrm{NO}_{3}{ }^{-} \mathrm{N} /$ ha were reported from a newly seeded kentucky bluegrass (Poa pratensis L.)-perennial ryegrass (Lolium perenne L.) mix (80\%:20\%, w/w) grown on a sandy loam soil (Easton and Petrovic, 2004) and during the second year, leaching losses declined to $22 \mathrm{~kg}$ $\mathrm{NO}_{3}^{-} \mathrm{N} /$ ha. Soluble organic $\mathrm{N}$ sources (urea) were subject to leaching while manure composts and biosolids leached much less nitrate,

Received for publication 11 Oct. 2005. Accepted for publication Nov. 42005 . Authors would like to thank Tom Duff for his help during the study.

1Corresponding author; e-mail haibol@clemson. edu.
64 and $9 \mathrm{~kg} \mathrm{NO}_{3}^{-} \mathrm{N} / \mathrm{ha}$, for establishment and post-establishment years, respectively.

Nitrogen efficiency of managed turf has been achieved by employing slowly soluble $\mathrm{N}$ carriers, timing applications better to meet turfgrass needs, adjusting irrigation to minimize excess drainage and selecting genotypes that are more efficient in recovering nitrate from the soil (Hull et al., 1994; Liu et al., 1993). However, cool-season lawn or fairway turf continues to receive 50 to $175 \mathrm{~kg} \mathrm{~N} / \mathrm{ha} /$ year depending on the species and intensity of management (Beard, 1973; Petrovic, 1990).

Nitrogen use on turf is increasingly being analyzed from a system perspective where mass balance of $\mathrm{N}$ within the turf-soil ecosystem becomes the basis for $\mathrm{N}$ fertilization (Easton and Petrovic, 2004; Engelsjord et al., 2004; Horgan et al., 2002). This approach depends upon identifying and quantifying all sources and losses of $\mathrm{N}$ within turf-soil systems and understanding their dynamics over both short (months) and long (years) intervals. This information has been collected over the past 20 years and is being assimilated into models that describe $\mathrm{N}$ fluxes through various compartments of turf-soil systems and to identify limiting factors affecting turfgrass performance (Qian et al., 2003).

Isotopic studies involving ${ }^{15} \mathrm{~N}$ have determined partitioning of fertilizer $\mathrm{N}$ among various compartments of turf-soil system
(Engelsjord et al., 2004; Horgan et al., 2002; Miltner et al., 1996; Starr and DeRoo, 1981). Clippings of kentucky bluegrass and perennial ryegrass collected throughout the growing season contained about $45 \%$ of labeled fertilizer N(LFN); thatch-mat contained 20\%/10\% of LFN, verdure contained $2 \%$ and soil (40 cm depth) contained $12 \%$ of LFN 365 d after fertilizer application (Engelsjord et al., 2004). Of the LFN applied, about $72 \%$ was recovered after one year, the remaining $28 \%$ being lost through denitrification, volatilization of ammonia, leaching of nitrate or in collection and processing of samples. It was also noted that thatch, defined as undecomposed organic matter including rhizomes, initially immobilized about $35 \%$ of LFN but as mineralization of these organic residues progressed, label $\mathrm{N}$ in thatch decreased and soil LFN increased often exceeding $20 \%$ of fertilizer $\mathrm{N}$.

Clipping $\mathrm{N}$ was variable in most of these experiments since it was removed during sampling and not recycled to the soil. Only Starr and DeRoo (1981) returned clippings to plots from which they were harvested and clipping-N (current season and past years) amounted to $50 \mathrm{~kg} \mathrm{~N} / \mathrm{ha}$ and accounted for $30 \%$ of $\mathrm{N}$ used by turf. They concluded that if clippings were retained, applications of fertilizer $\mathrm{N}$ could be reduced by one-third. Kopp and Guillard (2002) concluded that clipping retention on established turf could justify reducing $\mathrm{N}$ applications by $50 \%$ or more due to $\mathrm{N}$ supplied by clippings.

Clippings can return substantial amounts of $\mathrm{N}$ to turf-soil system. In northern California, Harivandi et al. (2001) obtained clipping dry matter yields of $4724 \mathrm{~kg} \cdot \mathrm{ha}^{-1} \cdot$ year $^{-1}$ from turf composed of kentucky bluegrass and perennial ryegrass. These clippings contained 156 $\mathrm{kg} \mathrm{N} /$ ha that almost equaled fertilizer $\mathrm{N}$ applied $\left(195 \mathrm{~kg} \cdot \mathrm{ha}^{-1} \cdot \mathrm{year}^{-1}\right)$ as $\left(\mathrm{NH}_{4}\right)_{2} \mathrm{SO}_{4}$. They observed that mowing with a recycling mower enhanced turf quality but did not alter turf density or texture. In Michigan, Engelsjord et al. (2004) obtained annual clipping yields of $7680 \mathrm{~kg} \cdot \mathrm{ha}^{-1}$ dry matter containing $258 \mathrm{~kg}$ $\mathrm{N} /$ ha from kentucky bluegrass turf and 7850 $\mathrm{kg} \cdot \mathrm{ha}^{-1}$ containing $241 \mathrm{~kg} \mathrm{~N} / \mathrm{ha}$ from perennial ryegrass. Annual $\mathrm{N}$ applications totaled $293 \mathrm{~kg} \cdot \mathrm{ha}^{-1}$ explaining greater clipping yields and $\mathrm{N}$ recovery than that reported for the California study.

Clippings contribute substantially to annual $\mathrm{N}$ budgets of turf-soil ecosystems and this must be factored into any turf management strategy designed to increase $\mathrm{N}$ use efficiency and minimize $\mathrm{N}$ losses to surface and ground waters (Heckman et al., 2000; Bigelow, 2005). However, turfgrasses differ in clipping production and $\mathrm{N}$ content as do cultivars of turf species (Liu et al., 1993). Differences in clipping management of various turfgrasses might influence efficiency of $\mathrm{N}$ use for longterm fertilization and culture.

To test this hypothesis, experiments compared cultivars of three field grown cool season turfgrasses for growth and clipping $\mathrm{N}$ recovery under a moderate $\mathrm{N}$ fertilization regime over two growing seasons. Findings may provide quantitative assessments of potential contributions clipping management can make 
toward designing strategies for reducing $\mathrm{N}$ fertilization of turf.

\section{Materials and Methods}

Ten cultivars each of kentucky bluegrass, perennial ryegrass, and tall fescue, listed in Tables 2 through 5, were randomly selected from National Turfgrass Evaluation Program (NTEP) trials planted as randomized complete block design with three replications. These evaluation trials had been seeded in 1985 , 1986, or 1987 at the C.R. Skogley Turf Research Center of the Rhode Island Agricultural Experiment Station, Kingston, R.I., on an Enfield silt loam (Coarse loamy over sandy skeletal, mixed, mesic, Typic Dystrochrepts) of $\mathrm{pH}$ 6.5. Plots received $147 \mathrm{~kg} \mathrm{~N} / \mathrm{ha} /$ year in granular form as three equal applications of $49 \mathrm{~kg} \mathrm{~N} / \mathrm{ha}$ in April, June and November.
Fifty percent of applied $\mathrm{N}$ was ammonium nitrate with the remainder as urea $(25 \%)$ and methylene urea (25\%).

Experiments were conducted on mature turf during two growing seasons of 1990 and 1991. Plots were mowed twice weekly from May to October with clippings returned except when clipping samples were collected. A manually powered reel mower set at $3.8 \mathrm{~cm}$ mowing height with collecting basket attached was used for harvesting clippings from a sampling area measuring $0.48 \times 1.5 \mathrm{~m}$ of each $1.0 \times 2.0 \mathrm{~m}$ plot. Clippings were harvested biweekly and clipping contamination from adjacent plots was minimized by only harvesting one half $(0.48 \mathrm{~m}$ of $1.0 \mathrm{~m})$ of the width of each plot and a reduced length $(1.5$ of $2.0 \mathrm{~m})$ of sampling area of $0.72 \mathrm{~m}^{2}$ of total plot area of 2.0 $\mathrm{m}^{2}$. Plots were irrigated only when necessary to avoid drought stress and accumulatively amounted to 330 and $250 \mathrm{~mm}$ in 1990 and 1991, respectively.

Clippings were oven dried at $75^{\circ} \mathrm{C}$ for 48 hours, weighed and ground in Wiley mill to pass a 40-mesh screen. For both growing seasons, daily clipping growth rates (DCG) were calculated as biweekly clipping yield times 0.285 (4/14) since turf was mowed 4 times within each 14-d period and clippings from one of four mowings were collected and analyzed. Total $\mathrm{N}$ concentration of clippings (NC) was determined using a semimicro-Kjeldahl procedure (Eastin, 1978). This method analyzed both reduced and oxidized $\mathrm{N}$ by including one-hour predigestion in 30 sulfuric acid :1 salicylic acid $(\mathrm{v} / \mathrm{w})$ at room temperature and reduced all $\mathrm{NO}_{3}^{-}$and $\mathrm{NO}_{2}^{-}$to $\mathrm{NH}_{4}^{+}$before standard Kjeldahl digestion of organic N. Daily N recovery in clippings (DNR) was calculated by multiplying DCG by NC (Liu et al, 1993).

Table 1. Monthly growth and nitrogen recovery in clippings for three turfgrass species: tall fescue (TF), kentucky bluegrass (KB), and perennial ryegrass (PR) (mean of 10 cultivars each of 1990 and 1991).

\begin{tabular}{|c|c|c|c|c|c|c|c|}
\hline Species & May & June & July & August & September & October & Average \\
\hline \multicolumn{8}{|c|}{ Daily clipping growth (g dry tissue $/ \mathrm{m}^{2} / \mathrm{d}$ ) } \\
\hline KB & $2.9 \mathrm{~b}$ & $3.3 \mathrm{~b}$ & $3.2 \mathrm{a}$ & $2.2 \mathrm{a}$ & $1.5 \mathrm{a}$ & 1.5 & $2.5 \mathrm{~b}$ \\
\hline PR & $4.5 \mathrm{a}$ & $2.3 \mathrm{c}$ & $1.3 \mathrm{~b}$ & $1.1 \mathrm{~b}$ & $1.2 \mathrm{~b}$ & 1.6 & $2.0 \mathrm{c}$ \\
\hline \multicolumn{8}{|c|}{ Nitrogen content (mg N/g dry tissue) } \\
\hline $\mathrm{TF}$ & $36.0 \mathrm{c}^{\mathrm{z}}$ & $31.6 \mathrm{c}$ & $35.9 \mathrm{c}$ & $43.6 \mathrm{~b}$ & $38.5 \mathrm{~b}$ & $39.4 \mathrm{~b}$ & $37.3 \mathrm{c}$ \\
\hline $\mathrm{KB}$ & $41.7 \mathrm{a}$ & $37.4 \mathrm{a}$ & $45.2 \mathrm{a}$ & $49.0 \mathrm{a}$ & $45.3 \mathrm{a}$ & $43.4 \mathrm{a}$ & $43.4 \mathrm{a}$ \\
\hline PR & $38.0 \mathrm{~b}$ & $35.2 \mathrm{~b}$ & $42.9 \mathrm{~b}$ & $49.1 \mathrm{a}$ & $45.0 \mathrm{a}$ & $44.0 \mathrm{a}$ & $42.1 \mathrm{~b}$ \\
\hline $\mathrm{KB}$ & $123.0 \mathrm{~b}$ & $125.1 \mathrm{a}$ & $140.8 \mathrm{a}$ & $109.3 \mathrm{a}$ & $72.5 \mathrm{a}$ & 69.0 & $107.3 \mathrm{a}$ \\
\hline PR & $164.6 \mathrm{a}$ & $78.1 \mathrm{~b}$ & $64.7 \mathrm{c}$ & $53.0 \mathrm{~b}$ & $56.9 \mathrm{~b}$ & 69.8 & $81.2 \mathrm{~b}$ \\
\hline
\end{tabular}

${ }^{2}$ Means in a column for each clipping parameter followed by the same letter are not significantly different at $p<0.05$ based on Duncan's multiple range test.

Table 2. Daily clipping growth rate (DCG) for 10 cultivars each of kentucky bluegrass, perennial ryegrass, and tall fescue (monthly means for 1990 and 1991 ).

\begin{tabular}{|c|c|c|c|c|c|c|c|}
\hline Cultivar & \multicolumn{7}{|c|}{ Growth rate $\left(\mathrm{g}\right.$ dry tissue $\left./ \mathrm{m}^{2} / \mathrm{d}\right)$} \\
\hline Kenblue & $4.6 \mathrm{a}^{\mathrm{z}}$ & $3.8 \mathrm{~b}$ & 4.2 & $2.7 \mathrm{a}$ & $2.1 \mathrm{a}$ & $1.9 \mathrm{a}$ & $3.2 \mathrm{a}$ \\
\hline Able I & $2.0 \mathrm{c}$ & $4.1 \mathrm{a}$ & 4.1 & $2.6 \mathrm{ab}$ & $2.1 \mathrm{a}$ & $2.0 \mathrm{a}$ & $2.9 \mathrm{a}$ \\
\hline Trenton & $3.6 \mathrm{a}-\mathrm{c}$ & $3.6 \mathrm{ab}$ & 3.2 & $2.3 \mathrm{ab}$ & $1.7 \mathrm{ab}$ & $1.3 \mathrm{ab}$ & $2.7 \mathrm{ab}$ \\
\hline Bristol & $2.9 \mathrm{a}-\mathrm{c}$ & $3.2 \mathrm{a}-\mathrm{c}$ & 3.0 & $2.6 \mathrm{ab}$ & $2.1 \mathrm{a}$ & $2.0 \mathrm{a}$ & $2.7 \mathrm{ab}$ \\
\hline Eclipse & $2.4 \mathrm{bc}$ & $3.5 \mathrm{ab}$ & 2.9 & $2.6 \mathrm{ab}$ & $1.6 \mathrm{ab}$ & $1.5 \mathrm{ab}$ & $2.5 \mathrm{bc}$ \\
\hline Blacksburg & $1.8 \mathrm{c}$ & $2.4 \mathrm{c}$ & 2.9 & $2.2 \mathrm{ab}$ & $1.0 \mathrm{c}$ & $1.0 \mathrm{~b}$ & $1.9 \mathrm{c}$ \\
\hline \multicolumn{8}{|l|}{ Perennial ryegrass } \\
\hline Linn & 4.9 & 2.7 & 1.5 & $1.1 \mathrm{ab}^{\mathrm{z}}$ & $1.5 \mathrm{a}$ & 1.8 & $2.3 \mathrm{a}$ \\
\hline $\mathrm{J}-207$ & 4.5 & 2.4 & 1.6 & $1.4 \mathrm{a}$ & $1.5 \mathrm{a}$ & 2.1 & $2.2 \mathrm{a}$ \\
\hline PST-2PM & 5.3 & 2.5 & 1.3 & $0.9 \mathrm{ab}$ & $1.1 \mathrm{ab}$ & 1.5 & $2.1 \mathrm{ab}$ \\
\hline Derby & 4.4 & 2.1 & 1.4 & $1.2 \mathrm{ab}$ & $1.3 \mathrm{a}$ & 1.7 & $2.0 \mathrm{ab}$ \\
\hline Tara & 4.0 & 1.8 & 0.8 & $0.7 \mathrm{~b}$ & $0.6 \mathrm{~b}$ & 1.1 & $1.5 \mathrm{~b}$ \\
\hline \multicolumn{8}{|l|}{ Tall fescue } \\
\hline P-164 & 5.2 & $4.2 \mathrm{ab}^{\mathrm{z}}$ & 2.6 & 2.8 & $2.1 \mathrm{a}$ & $2.1 \mathrm{a}$ & $3.2 \mathrm{a}$ \\
\hline P-160 & 5.3 & $3.6 \mathrm{ab}$ & 2.8 & 2.9 & $1.9 \mathrm{ab}$ & $2.3 \mathrm{a}$ & $3.1 \mathrm{ab}$ \\
\hline Kentucky-31 & 4.9 & $4.3 \mathrm{ab}$ & 2.7 & 2.7 & $1.7 \mathrm{ab}$ & $2.1 \mathrm{a}$ & $3.1 \mathrm{ab}$ \\
\hline Falcon & 4.9 & $4.3 \mathrm{a}$ & 2.7 & 2.8 & $1.7 \mathrm{ab}$ & $1.6 \mathrm{ab}$ & $3.1 \mathrm{ab}$ \\
\hline Jaguar & 5.7 & $3.7 \mathrm{ab}$ & 2.6 & 2.6 & $1.6 \mathrm{ab}$ & $1.6 \mathrm{ab}$ & $3.0 \mathrm{ab}$ \\
\hline Arid & 5.0 & $4.0 \mathrm{ab}$ & 2.8 & 2.5 & $1.6 \mathrm{ab}$ & $1.3 \mathrm{ab}$ & $2.9 \mathrm{ab}$ \\
\hline Rebel II & 4.9 & $3.6 \mathrm{ab}$ & 2.8 & 2.7 & $1.4 \mathrm{a}-\mathrm{c}$ & $1.4 \mathrm{ab}$ & $2.8 \mathrm{ab}$ \\
\hline Apache & 5.2 & $3.3 \mathrm{ab}$ & 2.3 & 2.5 & $1.6 \mathrm{ab}$ & $1.5 \mathrm{ab}$ & $2.8 \mathrm{ab}$ \\
\hline SYN GA & 4.0 & $3.4 \mathrm{ab}$ & 2.0 & 2.0 & $1.3 \mathrm{bc}$ & $1.1 \mathrm{ab}$ & $2.4 \mathrm{bc}$ \\
\hline PST-5AG & 3.6 & $2.7 \mathrm{~b}$ & 1.8 & 1.5 & $0.8 \mathrm{c}$ & $0.8 \mathrm{~b}$ & $1.9 \mathrm{c}$ \\
\hline
\end{tabular}

${ }^{2}$ Means in a column for each species followed by the same letter are not significantly different at $p<0.05$ based on Duncan's multiple range test. 
Cultivar plots within each species trial were arranged in a randomized complete block design with three replications. Plots of three species were treated as incomplete split plots (Lentner and Bishop, 1986) with 10 cultivars serving a replication for each species. Data were subjected to analysis of variance using Proc GLM with Statistical Analysis System (SAS Institute Inc., 1990). Means were separated with Duncan's multiple range test. Years were combined since interactions were not detected with parameters measured. One of every four clipping harvests was analyzed to reduce unnecessary work since no differences in both clipping yield and chemical analysis were found within any 2 -week period for four clipping harvests collected.

\section{Results and Discussion}

\section{Species Comparisons}

Significant differences in clipping growth and $\mathrm{N}$ recovery in clippings were generally noted among the three species throughout the growing seasons except in October when only differences in $\mathrm{N}$ content were detected (Table 1). Greater variation in clipping growth and $N$ recovery rates was evident during May, June, and July than other dates. Clipping yields and recovered $\mathrm{N}$ in May and June were more than twice those of September and October. This likely reflected growth activity of cool-season grasses during the spring (Turgeon, 2005) before soil temperatures increased. Nitrogen concentration in clippings of all three turfgrasses increased more than 30\% between June and August coinciding with their decline in clipping growth rate and an increase in soil water nitrate (Geron et al., 1993; Liu et al., 1997).

Kentucky bluegrass had slower growth in May while perennial ryegrass exhibited greater clipping growth and $\mathrm{N}$ recovery rates but these declined by $50 \%$ during June and reached their lowest levels during August (Table 1). Tall fescue followed similar seasonal clipping yield and $\mathrm{N}$ recovery pattern but maintained significantly greater rates than perennial ryegrass during most of summer. All grasses were least active during September with only perennial ryegrass exhibiting signs of recovery during October.

Following a decline from May to June, leaf $\mathrm{N}$ content increased in all grasses through August (Table 1). In general, DCG rates and DNR rates were positively correlated while $\mathrm{NC}$ and DNR were negatively correlated in all grasses (Liu et al., 1993).

\section{Cultivar comparisons}

DCG rates. Significant differences in DCG rates were detected among kentucky bluegrass cultivars during all months except July (Table 2). Cultivar differences were observed only twice in perennial ryegrass (August and September) and three times in tall fescue (June, September and October). Generally, cultivars with the lowest average clipping growth rates were consistently low yielding during spring, summer and fall. Cultivars exhibiting high DCG rates in spring were less consistent throughout the season. Clipping growth rates among cultivars during any month did not exceed a two-fold difference. In general, all cultivars of three species showed greater DCG rates during spring and early summer than during late summer and fall consistent with seasonal growth patterns for cool-season grasses (Christians, 2004; Turgeon 2005). Greater frequency of significant differences in clipping growth rates among kentucky bluegrass cultivars may reflect its broader genetic base than that of perennial ryegrass and tall fescue (Funk et al., 1993).

Total clipping yields for tall fescue, kentucky bluegrass and perennial ryegrass averaged 5152,4600 , and $3680 \mathrm{~kg}$ dry mass ha ${ }^{-1}$ for the two seasons. These values are comparable to that reported by Harivandi et al. (2001) for a kentucky bluegrass-perennial ryegrass mixture $\left(4724 \mathrm{~kg} \cdot \mathrm{ha}^{-1}\right)$ and by Engelsjord et al. (2004) for kentucky bluegrass $\left(7680 \mathrm{~kg} \cdot \mathrm{ha}^{-1}\right)$ and perennial ryegrass $\left(7850 \mathrm{~kg} \cdot \mathrm{ha}^{-1}\right)$. Latter experiment used two times $\mathrm{N}$ rate applied in our study (293 vs. $147 \mathrm{~kg} \mathrm{~N} / \mathrm{ha} /$ year).

$N C$. Significant differences in NC were observed less frequently among cultivars than were differences in clipping growth rates (Table $3)$. Clipping $\mathrm{N}$ content differed significantly during only one, three and three months for kentucky bluegrass, perennial ryegrass and tall fescue, respectively. Clipping N levels among cultivars always differed significantly in June but not May (Table 3) although differences were greater in May. During May, soil $\mathrm{NO}_{3}^{-}$had been largely depleted (Liu et al.,

Table 3. Nitrogen concentration (NC) of clippings for 10 cultivars each of kentucky bluegrass, perennial ryegrass, and tall fescue (monthly means for 1990 and 1991).

\begin{tabular}{|c|c|c|c|c|c|c|c|}
\hline Cultivar & \multicolumn{7}{|c|}{ NC (mg N/g dry tissue) } \\
\hline Bristol & 42.3 & $38.2 \mathrm{ab}^{\mathrm{z}}$ & 47.1 & 51.3 & 47.5 & 45.0 & $45.0 \mathrm{a}$ \\
\hline Midnight & 45.4 & $39.6 \mathrm{a}$ & 46.1 & 48.9 & 45.4 & 44.6 & $44.8 \mathrm{ab}$ \\
\hline Eclipse & 42.5 & $37.8 \mathrm{ab}$ & 45.8 & 49.6 & 44.2 & 42.8 & $43.6 \mathrm{ab}$ \\
\hline Able I & 42.3 & $36.9 \mathrm{a}-\mathrm{c}$ & 44.6 & 48.8 & 45.9 & 4.4 & $43.5 \mathrm{ab}$ \\
\hline Liberty & 41.0 & $37.2 \mathrm{a}-\mathrm{c}$ & 45.9 & 48.6 & 45.4 & 43.4 & $43.3 \mathrm{ab}$ \\
\hline Parade & 41.3 & $34.5 \mathrm{c}$ & 43.3 & 47.9 & 45.1 & 42.1 & $42.1 \mathrm{~b}$ \\
\hline \multicolumn{8}{|l|}{ Perennial ryegrass } \\
\hline Repel & 38.9 & $37.5 \mathrm{a}^{\mathrm{z}}$ & $50.8 \mathrm{a}$ & 50.3 & $43.9 \mathrm{~b}$ & 45.3 & 44.4 \\
\hline Yorktown & 27.3 & $35.8 \mathrm{ab}$ & $44.0 \mathrm{ab}$ & 48.6 & $54.4 \mathrm{a}$ & 44.3 & 42.4 \\
\hline PST-2PM & 40.0 & $33.9 \mathrm{ab}$ & $41.7 \mathrm{~b}$ & 49.6 & $44.4 \mathrm{~b}$ & 44.2 & 42.3 \\
\hline $\mathrm{J}-207$ & 38.6 & $35.9 \mathrm{ab}$ & $41.9 \mathrm{~b}$ & 49.5 & $45.2 \mathrm{~b}$ & 42.1 & 42.0 \\
\hline $\mathrm{J}-208$ & 37.5 & $34.4 \mathrm{ab}$ & $38.9 \mathrm{~b}$ & 50.1 & $43.2 \mathrm{~b}$ & 44.3 & 41.4 \\
\hline \multicolumn{8}{|l|}{ Tall fescue } \\
\hline Rebel & 38.3 & $33.9 \mathrm{a}^{\mathrm{z}}$ & 37.5 & $46.1 \mathrm{a}$ & 40.5 & $41.3 \mathrm{ab}$ & $39.4 \mathrm{a}$ \\
\hline P-160 & 37.1 & $31.3 \mathrm{ab}$ & 37.1 & $46.0 \mathrm{a}$ & 40.2 & $45.8 \mathrm{a}$ & $39.2 \mathrm{a}$ \\
\hline Jaguar & 38.3 & $34.0 \mathrm{a}$ & 37.4 & $44.4 \mathrm{a}$ & 38.3 & $38.8 \mathrm{bc}$ & $38.3 \mathrm{ab}$ \\
\hline Arid & 37.5 & $33.6 \mathrm{a}$ & 35.7 & $43.9 \mathrm{ab}$ & 39.7 & $38.6 \mathrm{bc}$ & $38.0 \mathrm{ab}$ \\
\hline Falcon & 36.4 & $32.2 \mathrm{ab}$ & 36.3 & $43.4 \mathrm{ab}$ & 38.5 & $38.9 \mathrm{bc}$ & $37.4 \mathrm{ab}$ \\
\hline P-164 & 36.0 & $30.7 \mathrm{ab}$ & 36.6 & $43.8 \mathrm{ab}$ & 38.5 & $39.4 \mathrm{bc}$ & $37.2 \mathrm{ab}$ \\
\hline PST-5AG & 34.8 & $33.3 \mathrm{a}$ & 36.5 & $43.4 \mathrm{ab}$ & 37.2 & $38.5 \mathrm{bc}$ & $37.0 \mathrm{ab}$ \\
\hline Kentucky-31 & 34.1 & $30.8 \mathrm{ab}$ & 35.0 & $43.4 \mathrm{ab}$ & 38.8 & $39.1 \mathrm{bc}$ & $36.6 \mathrm{ab}$ \\
\hline Apache & 35.7 & $30.3 \mathrm{ab}$ & 33.3 & $42.2 \mathrm{ab}$ & 38.1 & $38.5 \mathrm{bc}$ & $36.1 \mathrm{~b}$ \\
\hline SYN GA & 32.2 & $26.5 \mathrm{~b}$ & 33.7 & $39.7 \mathrm{~b}$ & 34.9 & $34.7 \mathrm{c}$ & $33.3 \mathrm{c}$ \\
\hline
\end{tabular}

${ }^{\mathrm{z}}$ Means in a column for each species followed by the same letter are not significantly different at $p<0.05$ based on Duncan's multiple range test. 
1997) and temperatures were still in optimum range for root growth and function $\left(<24^{\circ} \mathrm{C}\right)$ (Beard, 2002). However in June, additional fertilizer $\mathrm{N}$ was applied, mineralization of soil organic $\mathrm{N}$ might have increased and roots began to experience high temperature stress. Turfgrass responses to these June conditions are more likely to be under genetic control (nitrate absorption rate and transport to leaves, high temperature tolerance) resulting in greater cultivar variations in leaf $\mathrm{N}$ levels.

DNR in clippings. Similar to clipping growth rate data, daily $\mathrm{N}$ recovery in clippings exhibited significant differences among kentucky bluegrass cultivars during four of the six months (Table 4). By comparison, DNR rates differed significantly only during September for perennial ryegrass and tall fescue. Seasonal averages of DNR rates exhibited significant differences for all grasses. Daily clipping growth rates influenced the rate of $\mathrm{N}$ recovery in clippings more than NC of clippings.

During spring and early summer, trends in N recovery were cultivar specific especially for kentucky bluegrass. While 'Able I', 'Liberty', and 'Blacksburg' exhibited lowest DNR rates in May, they all increased dramatically through June to July; 'Able I' and 'Liberty' increased rapidly but 'Blacksburg' more slowly. By comparison, 'Kenblue', and 'Midnight' recovered $\mathrm{N}$ at a high rate in May but declined through June and July while 'Parade' did not show summer decline in clipping $\mathrm{N}$ recovery. More aggressive cultivars, e.g., 'Blacksburg', lose less leaf tissue during mowing and thus contributed less carbon and $\mathrm{N}$ to clippings. This conservation of resources and retention of more photosynthetic leaf surface likely contribute to aggressiveness of these grasses and genetic diversity (Bonos et al., 2000).

Less variation in seasonal pattern of DNR rates was evident in perennial ryegrass and tall fescue (Table 4). Greatest mean DNR rate for perennial ryegrass was observed in May when it was about two times that of any other month. This reflected high efficiency of both $\mathrm{NO}_{3}^{-}$(Liu et al., 1993; Bushoven and Hull, 2001; Bushoven and Hull, 2005) and $\mathrm{NH}_{4}^{+}$ (Clarkson et al., 1986) absorption by perennial ryegrass and its rapid transport of $\mathrm{NO}_{3}{ }^{-}$to leaves (Bushoven and Hull, 2001; Bushoven and Hull, 2005). However, upright growth of perennial ryegrass leaves may result in large $\mathrm{N}$ losses during mowing and may explain rapid decline in DCG and DNR rates following early season mowings.

\section{Discussion}

Results show $\mathrm{N}$ recovered in clippings was not only derived from current fertilizer applications, which is not unusual as demonstrated by several studies (Engelsjord et al., 2004; Miltner et al., 1996; Starr and DeRoo, 1981). These studies noted current season $\mathrm{N}$ applications contributed only $34 \%$ to $47 \%$ of total $\mathrm{N}$ recovered in clippings. Clipping $\mathrm{N}$ is derived from thatch, clippings from previous years and mineralized soil organic N. Clippings retained on turf contributed 30\% (Starr and
DeRoo, 1981) to 50\% (Kopp and Guillard, 2002) to current season N recovery in clippings. These authors suggest that fertilizer $\mathrm{N}$ can be reduced by $30 \%$ to $50 \%$ with no loss in turf quality when clippings are returned.

Studies with ${ }^{15} \mathrm{~N}$ labeling mentioned above also determined that $25 \%$ to $37 \%$ of applied fertilizer $\mathrm{N}$ becomes incorporated in soil organic matter over a 2 to 3 year period with the larger amounts incorporated when clippings are returned. As soil organic matter in turf-soil ecosystem increases with time, soil organic $\mathrm{N}$ will also increase also increase to $>2500 \mathrm{~kg} \mathrm{~N} / \mathrm{ha}$ (Hull and Liu, 2005; Petrovic, 1990; Qian et al., 2003). Plots used in this study were seeded on land that had been as managed as turf for at least 20 years and in grass-legume forage stands for previous 20 to 25 years. Analyses of total soil organic $\mathrm{N}$ had indicated levels of about $2300 \mathrm{~kg} \mathrm{~N} / \mathrm{ha}$. If only $4 \%$ of this soil organic $\mathrm{N}$ is mineralized each year, about $100 \mathrm{~kg} \mathrm{~N} / \mathrm{ha}$ will be rendered available to turfgrass roots. Adding this to the $200 \mathrm{~kg} \mathrm{~N} /$ ha provided by clippings returned to turf, a significant quantity of $\mathrm{N}$ is present and cycled through turf-soil system (Bigelow et al., 2005). Based on this analysis, there appears to be ample opportunity to increase N use efficiency in turfgrass management. Retaining clippings and accounting for the mineralized soil organic $\mathrm{N}$ should permit reductions in $\mathrm{N}$ fertilization of about $50 \%$ to $75 \%$ (Heckman et al., 2000). Achieving these economic and environmental advantages has promising implications for future research in turf $\mathrm{N}$ management.

Table 4. Daily N recovery rates in clippings (DNR) for 10 cultivars each of kentucky bluegrass, perennial ryegrass, and tall fescue (monthly means for 1990 and 1991).

\begin{tabular}{|c|c|c|c|c|c|c|c|}
\hline \multirow[b]{2}{*}{ Cultivar } & \multicolumn{7}{|c|}{$\mathrm{DNR}\left(\mathrm{mg} \mathrm{N} / \mathrm{m}^{2} / \mathrm{d}\right)$} \\
\hline & May & June & July & August & September & October & Average \\
\hline \multicolumn{8}{|c|}{ Kentucky bluegrass } \\
\hline Kenblue & $196.3 \mathrm{a}^{\mathrm{z}}$ & $149.7 \mathrm{a}$ & 185.3 & 132.8 & $93.7 \mathrm{ab}$ & $87.2 \mathrm{ab}$ & $141.2 \mathrm{a}$ \\
\hline Able I & $76.5 \mathrm{c}$ & $151.5 \mathrm{a}$ & 181.5 & 127.8 & $98.6 \mathrm{a}$ & $93.8 \mathrm{a}$ & $122.8 \mathrm{ab}$ \\
\hline Bristol & $117.0 \mathrm{a}-\mathrm{c}$ & $119.9 \mathrm{ab}$ & 140.6 & 132.6 & $103.5 \mathrm{a}$ & $94.2 \mathrm{a}$ & $118.0 \mathrm{a}-\mathrm{c}$ \\
\hline Joy & $166.2 \mathrm{a}-\mathrm{c}$ & $139.9 \mathrm{a}$ & 151.2 & 100.5 & $61.7 \mathrm{c}-\mathrm{e}$ & $60.5 \mathrm{ab}$ & $114.4 \mathrm{a}-\mathrm{d}$ \\
\hline Trenton & $138.2 \mathrm{a}-\mathrm{c}$ & $128.0 \mathrm{ab}$ & 144.5 & 116.0 & $72.9 \mathrm{a}-\mathrm{c}$ & $58.1 \mathrm{ab}$ & $111.5 \mathrm{a}-\mathrm{d}$ \\
\hline Eclipse & $95.6 \mathrm{bc}$ & $129.9 \mathrm{ab}$ & 128.9 & 126.1 & $74.9 \mathrm{a}-\mathrm{d}$ & $66.4 \mathrm{ab}$ & $105.0 \mathrm{~b}-\mathrm{d}$ \\
\hline Parade & $119.2 \mathrm{a}-\mathrm{c}$ & $114.2 \mathrm{ab}$ & 112.9 & 89.7 & $65.3 \mathrm{~b}-\mathrm{e}$ & $60.0 \mathrm{ab}$ & $94.4 \mathrm{~b}-\mathrm{d}$ \\
\hline Liberty & $88.1 \mathrm{bc}$ & $111.8 \mathrm{ab}$ & 147.6 & 95.9 & $58.1 \mathrm{c}-\mathrm{e}$ & $58.8 \mathrm{ab}$ & $93.9 \mathrm{~b}-\mathrm{d}$ \\
\hline Midnight & $146.3 \mathrm{a}-\mathrm{c}$ & $116.1 \mathrm{ab}$ & 87.4 & 64.9 & $42.3 \mathrm{e}$ & $63.8 \mathrm{ab}$ & $86.4 \mathrm{~cd}$ \\
\hline Blacksburg & $83.8 \mathrm{c}$ & $89.7 \mathrm{c}$ & 128.2 & 106.6 & $47.1 \mathrm{de}$ & $44.8 \mathrm{~b}$ & $83.6 \mathrm{~d}$ \\
\hline \multicolumn{8}{|l|}{ Perennial ryegrass } \\
\hline $\mathrm{J}-207$ & 167.8 & 84.0 & 80.0 & 68.5 & $69.7 \mathrm{a}^{\mathrm{z}}$ & 84.2 & $92.4 \mathrm{a}$ \\
\hline Linn & 175.9 & 91.9 & 65.9 & 58.3 & $68.0 \mathrm{a}$ & 81.2 & $90.4 \mathrm{a}$ \\
\hline PST-2PM & 210.8 & 85.0 & 73.6 & 48.0 & $55.9 \mathrm{ab}$ & 67.5 & $89.1 \mathrm{a}$ \\
\hline Ranger & 177.6 & 77.7 & 78.4 & 58.2 & $46.9 \mathrm{ab}$ & 69.2 & $84.6 \mathrm{ab}$ \\
\hline Derby & 153.7 & 72.2 & 67.3 & 61.0 & $64.8 \mathrm{a}$ & 76.7 & $81.6 \mathrm{ab}$ \\
\hline Repel & 148.4 & 89.8 & 70.3 & 52.1 & $62.0 \mathrm{a}$ & 58.1 & $81.1 \mathrm{ab}$ \\
\hline $\mathrm{J}-208$ & 154.4 & 76.9 & 57.0 & 48.2 & $53.6 \mathrm{ab}$ & 80.2 & $78.9 \mathrm{ab}$ \\
\hline Manhattan & 133.1 & 71.1 & 65.1 & 53.1 & $46.6 \mathrm{ab}$ & 68.8 & $76.8 \mathrm{ab}$ \\
\hline Yorktown & 145.8 & 68.1 & 58.3 & 48.6 & $62.4 \mathrm{a}$ & 67.3 & $75.0 \mathrm{ab}$ \\
\hline Tara & 147.6 & 64.3 & 39.9 & 33.8 & $29.6 \mathrm{~b}$ & 45.2 & $61.5 \mathrm{~b}$ \\
\hline \multicolumn{8}{|l|}{ Tall fescue } \\
\hline P-160 & 212.2 & 107.2 & 110.5 & 131.5 & $75.0 \mathrm{a}^{\mathrm{z}}$ & 96.8 & $121.6 \mathrm{a}$ \\
\hline Jaguar & 232.2 & 127.7 & 108.4 & 118.6 & $62.7 \mathrm{a}$ & 68.1 & $120.7 \mathrm{a}$ \\
\hline P-164 & 188.0 & 127.9 & 104.7 & 125.0 & $80.9 \mathrm{a}$ & 83.0 & $119.1 \mathrm{a}$ \\
\hline Falcon & 183.4 & 137.1 & 113.6 & 124.5 & $67.7 \mathrm{a}$ & 70.6 & $117.8 \mathrm{a}$ \\
\hline Arid & 195.4 & 137.7 & 112.5 & 112.6 & $67.1 \mathrm{a}$ & 54.5 & $115.1 \mathrm{a}$ \\
\hline Kentucky-31 & 174.5 & 129.1 & 100.9 & 119.3 & $68.5 \mathrm{a}$ & 75.8 & $112.6 \mathrm{a}$ \\
\hline Rebel II & 190.1 & 121.7 & 117.4 & 125.9 & $56.8 \mathrm{ab}$ & 61.0 & $112.6 \mathrm{a}$ \\
\hline Apache & 191.1 & 98.2 & 75.8 & 111.0 & $64.0 \mathrm{a}$ & 58.5 & $100.2 \mathrm{ab}$ \\
\hline SYN GA & 139.4 & 86.3 & 74.9 & 81.5 & $48.3 \mathrm{ab}$ & 44.6 & $79.9 \mathrm{~b}$ \\
\hline PST-5 AG & 125.4 & 89.3 & 95.3 & 69.2 & $31.5 \mathrm{~b}$ & 34.5 & $74.6 \mathrm{~b}$ \\
\hline
\end{tabular}

${ }^{2}$ Means in a column for each species followed by the same letter are not significantly different at $p<0.05$ based on Duncan's multiple range test. 
In conclusion, results from this study indicate genetic variation exists in $\mathrm{N}$ recovery in clippings among three cool-season turfgrasses at both species and cultivar levels. Nitrogen recovered in clippings differed among turfgrass species of kentucky bluegrass and tall fescue than perennial ryegrass. Nitrogen recovery in clippings fluctuated seasonally for all species. Perennial ryegrass and tall fescue showed greatest in May while kentucky bluegrass showed greatest in July. Most grasses recovered more $\mathrm{N}$ in their clippings than was applied each year as fertilizer indicating substantial contributions from soil organic $\mathrm{N}$ in this long established turf plot area. Clipping $\mathrm{N}$ makes a significant contribution to the $\mathrm{N}$ budget of turf and increases as turf sites mature.

\section{Literature Cited}

Beard, J.B. 1973. Turfgrass science and culture. Prentice Hall, Englewood Cliffs, NJ

Beard, J.B. 2002. Turf management for golf courses. 2nd ed. Ann Arbor Press, Chelsea, Mich.

Bigelow, C.A., D.W. Waddill, and D.R. Chalmers. 2005. Turf-type fescue lawn turf response to added clippings. Intl. Turfgrass Soc. Res. J. 10:916-922.

Bonos, S.A., W.A. Meyer, and J.A. Murphy. 2000. Classification of kentucky bluegrass genotypes grown as spaced-plants. HortScience 35(5):910-913.

Bushoven, J.T. and R.J. Hull. 2001. Nitrogen use efficiency is linked to nitrate reductase activity and biomass partitioning between roots and shoots of perennial ryegrass and creeping bentgrass. Intl. Turfgrass Soc. Res. J. 9:245-252.

Bushoven, J.T. and R.J. Hull. 2005. The role of nitrate in modulating growth and partitioning of nitrate assimilation between roots and leaves of perennial ryegrass (Lolium perenne L.). Intl. Turfgrass Soc. Res. J. 10:834-840.
Christians, N.E. 2004. Fundamentals of turfgrass management. 2nd ed. John Wiley \& Sons Inc. Hoboken, N.J.

Clarkson, D.T., M.J. Hopper, and L.H.P. Jones. 1986. The effect of root temperature on the uptake of nitrogen and the relative size of the root system in Lolium perenne. I. Solutions containing both $\mathrm{NH}_{4}^{+}$and $\mathrm{NO}_{3}^{-}$. Plant Cell Environ. 9:535-545.

Eastin, E.F. 1978. Total nitrogen determination for plant material containing nitrate. Anal. Biochem. 85:591-594.

Easton, Z.M. and A.M. Petrovic. 2004. Fertilizer source effect on ground and surface water quality in drainage from turf. J. Environ. Qual. 33:645-655.

Engelsjord, M.E., B.E. Branham, and B.P. Horgan. 2004. The fate of nitrogen- 15 ammonium sulfate applied to kentucky bluegrass and perennial ryegrass turfs. Crop Sci. 44:1341-1347.

Funk, C.R., J.A. Murphy, and D.R. Huff. 1993. Turfgrass germplasm-diversity and vulnerability of perennial ryegrass, tall fescue and kentucky bluegrass. Agron. Abstr. 188.

Geron, C.A., T.K. Danneberger, S.J. Traina, T.J. Logan, and J.R. Street. 1993. The effects of establishment methods and fertilization practices on nitrate leaching from turfgrass. J. Environ. Qual. 22:119-125.

Harivandi, M.A., W.L. Hagan, and C.L. Elmore. 2001. Recycling mower effects on biomass, nitrogen recycling, weed invasion, turf quality, and thatch. Inter. Turfgrass Soc. Res. J. 9:882-885.

Heckman, J. R., H. Liu, W. Hill, M. DeMilia, and W.L. Anastasia. 2000. Kentucky bluegrass responses to mowing and nitrogen fertility management. J. Sustainable Agr. 15:25-33

Horgan, B.P., B.E. Branham, and R.L. Mulvaney. 2002. Mass balance of ${ }^{15} \mathrm{~N}$ applied to kentucky bluegrass including direct measurement of denitrification. Crop Sci. 42:1595-1601.

Hull, R.J., S.R. Alm, and N. Jackson. 1994. Toward sustainable lawn turf. p. 3-15 In: A.R.Leslie (ed.). Handbook of integrated pest management for turfgrass and ornamentals. Lewis Publ., Boca Raton, Fla.

Hull, R.J. and H. Liu. 2005. Turfgrass nitrogen: physiology and environmental impacts. Intl. Turfgrass Soc. Res. J. 10:962-975.

Kopp, K.L. and K. Guillard. 2002. Clipping management and nitrogen fertilization of turfgrass: growth, nitrogen utilization, and quality. Crop Sci. 42:1225-1231.

Liu, H., R.J. Hull, and D.T. Duff. 1993. Comparing cultivars of three cool-season turfgrasses for nitrate uptake kinetics and nitrogen recovery in the field. Intl. Turfgrass Soc. Res. J. 7:546-552.

Liu, H., R.J. Hull, and D.T. Duff. 1997. Comparing cultivars of three cool-season turfgrasses for soil water $\mathrm{NO}_{3}{ }^{-}$concentration and leaching potential. Crop Sci. 37:526-534.

Lentner, M. and T. Bishop. 1986. Experimental Design and Analysis, p. 349-376. Valley Book Co., Blacksburg, Va.

Miltner, E.D., B.E. Branhan, E.A. Paul, and P.E. Rieke. 1996. Leaching and mass balance of ${ }^{15} \mathrm{~N}$-labeled urea applied to a kentucky bluegrass turf. Crop Sci. 36:1427-1433.

Petrovic, A.M. 1990. The fate of nitrogenous fertilizers applied to turfgrass. J. Environ. Qual. 19:1-14.

Petrovic, A.M. and Z.M. Easton. 2005. The role of turfgrass management in the water quality of urban environments. Intl. Turfgrass Soc. Res. J. 10:55-69.

Qian, Y.L., W. Bandaranayake, W.J. Parton, B. Mecham, M.A. Harivandi, and A.R. Mosier. 2003. Long-term effects of clipping and nitrogen management in turfgrass on soil organic carbon and nitrogen dynamics: The CENTURY model simulation. J. Environ. Qual. 32:1694-1700.

SAS Institute, Inc. 1990. SAS/STAT user's guide. version 6. 4th ed. SAS Inst., Inc., Cary, N.C.

Starr, J.L. and H.C. DeRoo. 1981. The fate of nitrogen applied to turfgrass. Crop Sci. 21:531-536.

Turgeon, A.J. 2005. Turfgrass Management. 7th ed. Prentice Hall, Upper Saddle River, N.J. 